Vol. 2 No. 1 Februari 2022 e-ISSN : 2797-1031 | p-ISSN : 2797-0744

\title{
OPTIMALISASI HASIL BELAJAR IPA MATERI LISTRIK STATIS DENGAN MODEL PEMBELAJARAN QODE BERBANTU ALAT PERAGA PADA SISWA KELAS IX. SUMAYYAH DI SMP NEGERI 10 LANGSA TAHUN 2019
}

\author{
NURLINAWATI \\ SMP Negeri 10 Langsa \\ Email.nurlinawati.mnoer@gmail.com
}

\begin{abstract}
ABSTRAK
Penelitian ini bertujuan mengetahui optimalisasi hasil belajar IPA dengan penerapan model pembelajaran QODE berbantu alat peraga pada siswa kelas IX. Sumayyah di SMP Negeri 10 Langsa. Subjek di dalam penelitian ini adalah siswa kelas IX. Sumayyah di SMP Negeri 10 Langsa semester ganjil tahun pelajaran 2019/2020 berjumlah 23 siswa perempuan. Instrumen penelitian meliputi lembar observasi dan soal. Metode pengumpulan data yang digunakan yaitu observasi dan tes. Data dianalisis secara statistik menggunakan rumus persentase, apabila $\geq 85$ siswa tuntas belajar maka siklus dihentikan.Hasil penelitian menunjukkan ada peningkatan hasil belajar siswa pada Siklus I $60 \%$ siswa memperoleh nilai hasil belajar $\geq 80$ dan $70 \%$ siswa memperoleh nilai hasil belajar $\geq 80$ pada siklus II.
\end{abstract}

Kata kunci: hasil belajar, model QODE, alat peraga.

\section{ABSTRACT}

This study aims to determine the optimization of science learning outcomes by applying the QODE learning model assisted by teaching aids for class IX students. Sumayyah at SMP Negeri 10 Langsa. The subjects in this study were grade IX students. Sumayyah at SMP Negeri 10 Langsa in the odd semester of the 2019/2020 school year totaled 23 female students. Research instruments include observation sheets and questions. Data collection methods used are observation and tests. The data were statistically analyzed using the percentage formula, if 85 students finished studying then the cycle was stopped. The results showed there was an increase in student learning outcomes in Cycle I 60\% of students got learning outcomes 80 and $70 \%$ of students got learning outcomes 80 in the cycle II.

Keywords: Results of Learning, Question, Organizing, Doing and Evaluating (QODE) Learning, teaching aids.

\section{PENDAHULUAN}

Model pembelajaran $Q O D E$ merupakan model pembelajaran yang dikembangkan berdasarkan teori belajar konstruktivisme dan keterampilan bertanya. Tahap model pembelajaran $Q O D E$ terdiri atas empat tahap yaitu Questioning, Organizing, Doing, dan Evaluating. Model pembelajaran QODE yang efektif dalam pembelajaran IPA ditunjukkan dengan hasil belajar.

Tabel 1. Sintakmatik model pembelajaran $Q O D E$.

\begin{tabular}{|l|l|l|}
\hline \multicolumn{1}{|c|}{ Tahap } & \multicolumn{1}{|c|}{ Kegiatan Siswa } & \multicolumn{1}{c|}{ Kegiatan Guru } \\
\hline $\begin{array}{l}\text { Bertanya } \\
\text { (Questioning) }\end{array}$ & $\begin{array}{l}\text { - Siswa mengamati gambar yang } \\
\text { berhubungan dengan konsep }\end{array}$ & $\begin{array}{l}\bullet \text { Guru menayangkan gambar } \\
\text { yang berhubungan dengan }\end{array}$ \\
& $\begin{array}{l}\text { Siswa meyusun pertanyaan } \\
\text { konsep yang berhubungan } \\
\text { dengan gambar }\end{array}$ & $\begin{array}{l}\text { konsep dalam kehidupan sehari- } \\
\text { hari } \\
\end{array}$ \\
& $\begin{array}{l}\text { Guru membimbing siswa dalam } \\
\text { menyusun pertanyaan }\end{array}$ \\
\hline
\end{tabular}


Vol. 2 No. 1 Februari 2022 e-ISSN : 2797-1031 | p-ISSN : 2797-0744

\begin{tabular}{|c|c|c|}
\hline $\begin{array}{l}\text { Mengorganisasi } \\
\text { siswa } \\
\text { (Organizing) }\end{array}$ & $\begin{array}{l}\text { - Siswa diskusi kelompok untuk } \\
\text { membahas alternatif jawaban } \\
\text { tentang pertanyaan } \\
\text { - Siswa menyampaikan jawaban } \\
\text { hasil diskusi kelompok pada } \\
\text { diskusi kelas } \\
\text { - Siswa tanya jawab antara } \\
\text { kelompok penyaji dengan } \\
\text { kelompok lain } \\
\text { - Siswa membuat kesimpulan hasil } \\
\text { diskusi kelas }\end{array}$ & $\begin{array}{l}\text { - Guru membimbing diskusi } \\
\text { kelompok untuk menemukan } \\
\text { jawaban } \\
\text { - Guru membimbing siswa untuk } \\
\text { melaksanakan diskusi kelas } \\
\text { - Guru membimbing siswa untuk } \\
\text { menanggapi pertanyaan } \\
\text { - Guru membimbing siswa diskusi } \\
\text { kelas untuk membuat } \\
\text { kesimpulan }\end{array}$ \\
\hline $\begin{array}{l}\text { Mengumpulkan } \\
\text { data dan } \\
\text { mengolah data } \\
\text { (Doing) }\end{array}$ & $\begin{array}{l}\text { - Siswa merencanakan praktikum } \\
\text { yang berhubungan dengan hasil } \\
\text { diskusi kelas untuk membuktikan } \\
\text { kesimpulan diskusi kelas } \\
\text { - Siswa mengumpulkan data hasil } \\
\text { praktikum } \\
\text { - Siswa menyusun kesimpulan } \\
\text { berdasarkan praktikum melalui } \\
\text { diskusi kelas } \\
\text { - Siswa membuat rancangan untuk } \\
\text { dipresentasikan }\end{array}$ & $\begin{array}{l}\text { - Guru membimbing langkah } \\
\text { kerja kegiatan praktikum } \\
\text { - Guru mengadakan penilaian } \\
\text { kinerja praktikum } \\
\text { - Guru membimbing siswa untuk } \\
\text { memperoleh data praktikum } \\
\text { - Guru membimbing siswa } \\
\text { berdiskusi kelas untuk } \\
\text { menyusun kesimpulan } \\
\text { - Guru membimbing siswa } \\
\text { berdiskusi membuat rancangan } \\
\text { presentasi hasil praktikum }\end{array}$ \\
\hline $\begin{array}{l}\text { Mengevaluasi } \\
\text { hasil belajar } \\
\text { (Evaluating) }\end{array}$ & $\begin{array}{l}\text { - Setiap siswa secara berkelompok } \\
\text { mempresentasikan hasil kerjanya } \\
\text { melalui diskusi kelas } \\
\text { - Kelompok lain menanggapi hasil } \\
\text { kerja yang dipresentasikan }\end{array}$ & $\begin{array}{l}\text { - Guru mengevaluasi hasil belajar } \\
\text { siswa melalui presentasi }\end{array}$ \\
\hline
\end{tabular}

Kesulitan yang dialami para siswa SMP Negeri 10 Langsa disebabkan karena metode mengajar yang kurang menarik dan kurang bervariasi sehingga siswa kurang bersemangat dalam belajar. Dengan menerapkan berbagai macam metode mengajar yang bervariasi dan menarik diharapkan dapat meningkatkan semangat belajar siswa, sehingga dapat meningkatkan hasil belajar bidang studi IPA.

Salah satu dari sekian banyak model pembelajaran adalah Questioning, Organizing, Doing and Evaluating (QODE) berbantu alat peraga yang dikembangkan berdasarkan teori belajar konstruktivisme dan keterampilan bertanya. Pembelajaran ini terlihat sederhana namun diharapkan dapat meningkatkan semangat belajar siswa dan hasil belajarnya. Oleh karena itu maka peneliti menetapkan judul "Optimalisai Hasil Belajar IPA Materi Listrik Statis Melalui Model Pembelajaran QODE Berbantu Alat Peraga pada Siswa Kelas IX. Sumayyah di SMP Negeri 10 Langsa Tahun 2019".

Dari berbagai persoalan yang muncul dalam proses pembelajaran di kelas IX. Sumayyah SMP Negeri 10 Langsa ditemukan berbagai masalah yang terjadi dalam proses pembelajaran bidang studi IPA yaitu:

1. Belum ditemukannya model pembelajaran yang tepat untuk meningkatkan hasil belajar bidang studi IPA.

2. Hasil belajar bidang studi IPA yang kurang memuaskan.

3. Metode pembelajaran yang digunakan masih monoton, kurang bervariasi.

4. Keaktifan siswa masih kurang dalam kegiatan belajar mengajar. 
Dengan melihat berbagai persoalan yang muncul dalam proses pembelajaran IPA di kelas IX.Sumayyah SMP Negeri 10 Langsa dapat ditetapkan rumusan masalahnya, yaitu: "Apakah melalui model pembelajaran QODE berbantu alat peraga dapat mengoptimalkan hasil belajar IPA materi Listrik Statis pada siswa kelas IX. Sumayyah di SMP Negeri 10 Langsa tahun 2019?"

\section{METODE PENELITIAN}

Tempat dilakukannya penelitian adalah di kelas IX.Sumayyah SMP Negeri 10 Langsa. Waktu penelitian dimulai bulan Oktober sampai dengan Desenber 2019 yakni pada semester ganjil 2019/2020. Kelas IX.Sumayyah dipilih sebagai subjek penelitian karena kelas IX.Sumayyah merupakan kelas yang paling banyak mengalami kesulitan belajar bidang studi IPA, berdasarkan nilai ulangan terakhir kelas IX.Sumayyah yang mempunyai siswa terbanyak mendapat nilai dibawah Kriteria Ketuntasan Minimal (KKM).

Penelitian ini merupakan penelitian tindakan kelas, yang prosedur penelitiannya menggunakan model yang dikembangkan oleh Kurt Lewin yang didasarkan atas konsep pokok penelitian tindakan, terdiri dari empat komponen pokok, yaitu:

1. Perencanaan atau planning

2. Tindakan atau acting

3. Pengamatan atau observing, dan

4. Refleksi atau reflecting. (Suharsimi Arikunto, 2006:92)

Hubungan antara keempat komponen tersebut menunjukkan sebuah siklus atau kegiatan berulang. "Siklus" inilah yang sebetulnya menjadi salah satu ciri utama dari penelitian tindakan, yaitu bahwa penelitian tindakan harus dilaksanakan dalam bentuk siklus, bukan hanya satu kali intervensi. Sumber data dalam penelitian ini diambil dari siswa selama proses pembelajaran dengan menerapkan model pembelajaran QODE berbantu alat peraga.

Dilihat dari asalnya, data dibedakan menjadi data primer dan data sekunder. Sumber data primer diperoleh dari nilai ulangan harian. Data dari pengamat teman sejawat termasuk data sekunder. Sumber data sekunder diperoleh dari hasil pengamatan yang dilakukan kolaborator.

Dilihat dari bentuk data, ada 2 (dua) macam data yaitu data kuantitatif dan kualitatif. Data hasil belajar merupakan data kuantitatif. Dilihat dari banyaknya data ada 3 (tiga), yaitu data kondisi awal tentang hasil belajar siswa, data siklus I tentang hasil belajar IPA, serta data siklus II tentang hasil belajar IPA. Adapun data kondisi awal tentang hasil belajar dapat diperoleh dari daftar nilai siswa.

\section{HASIL DAN PEMBAHASAN}

\section{Hasil Penelitian}

Ketuntasan hasil belajar berdasarkan hasil tes kondisi awal adalah sebesar $24 \%$, terdapat 19 siswa dari 25 siswa yang belum tuntas belajar. Pada kondisi awal ini belum digunakan model pembelajaran QODE sehingga hasil belajar IPA belum maksimal, artinya masih banyak siswa yang belum mencapai KKM.

\section{Siklus I}

dilakukan dengan tahapan-tahapan sebagai berikut :

1. Perencanaan ( planning) siklus I

a. Penyusunan rencana pelaksanaan pembelajaran yang dilengkapi dengan instrumen penilaian, model pembelajaran QODE, dan lembar observasi.

b. Penyusunan Rencana Pelaksanaan Pembelajaran (RPP) dilakukan dengan cara memperbaiki dengan menyesuaikan program pembelajaran yang telah dibuat di awal semester. RPP disusun sesuai dengan menerapkan model pembelajaran QODE berbantu alat peraga. 
c. Pembuatan alat peraga dilakukan dengan memperhatikan dasar teori dari materi muatan listrik tersebut.

d. Pembuatan lembar penilaian pengetahuan untuk mengetahui hasil belajar siswa.

2. Pelaksanaan (acting) siklus I

a. Guru menyiapkan peserta didik secara psikis dan fisik untuk mengikuti proses pembelajaran kemudian memberikan pertanyaan awal untuk mengetahui pengetahuan siswa mengenai materi Interaksi Antara Dua Muatan Listrik dan menjelaskan cakupan materi.

b. Guru menayangkan gambar dan membimbing siswa dalam menyusun pertanyaan.

c. Guru membimbing diskusi kelompok untuk menemukan jawaban dan membuat kesimpulan.

d. Guru membimbing langkah kerja kegiatan praktikum dan berdiskusi membuat rancangan presentasi hasil praktikum.

e. Guru mengevaluasi hasil belajar siswa melalui presentasi.

f. Guru memberikan penghargaan kepada kelompok yang hasilnya bagus, bersamasama dengan peserta didik membuat rangkuman/simpulan pelajaran kemudian memberikan umpan balik terhadap proses dan hasil pembelajaran.

3. Pengamatan tindakan (observing) siklus I

Penilaian harian dalam bentuk tes tertulis dilakukan pada akhir siklus I untuk mendapatkan data hasil belajar siswa. Dari hasil tes tertulis siklus I diperoleh nilai terendah 45, nilai tertinggi 85 dan rerata nilai 69,6. Terdapat 15 siswa (60\%) memperoleh nilai hasil belajar IPA $\geq 80$ atau tuntas KKM.

4. Refleksi siklus I

Pada siklus I telah dilaksanakan pembelajaran dengan menggunakan LKPD tanpa alat peraga pada materi Hukum Coulomb. Hasil belajar siswa mengalami peningkatan dibandingkan dengan kondisi awal. Jika dibandingkan dengan kondisi awal, nilai terendah naik $6,25 \%$ dari 40 menjadi 45 . Nilai tertinggi naik $6,25 \%$ juga dari 80 menjadi 85. Rata-rata nilai naik $26 \%$ dari 55,2 menjadi 69,6 . Persentase jumlah siswa yang telah tuntas belajar juga meningkat.

Dalam pelaksanaan tindakan ada beberapa hal yang menjadi catatan, yaitu:

a. Proses pembelajaran kurang menarik karena siswa hanya terpaku pada soal-soal yang ada pada LKPD

b. Guru perlu memberikan perhatian lebih kepada anggota kelompok yang cenderung individual.

c. Guru perlu lebih tegas menegur siswa yang cenderung pasif atau tidak serius, bercakap-cakap dan bahkan bermain-main dengan teman.

Karena hasil belajar pada siklus pertama belum dapat mencapai indikator yang ditetapkan maka perlu dilakukan siklus II untuk memperbaiki siklus yang pertama.

\section{Siklus II}

1. Perencanaan (planing) siklus II

RPP disusun sesuai dengan model RPP yang dilengkapi pembuatan alat peraga. Pembuatan alat peraga dilakukan dengan mempertimbangkan hasil refleksi tindakan siklus I. Proses pembelajaran yang semula mengandalkan soal-soal pada LKPD dirasa kurang maksimal hasil belajarnya sehingga pada siklus II ini dibuatlah alat peraga dan langsung dapat di uji coba.

2. Pelaksanaan tindakan (acting) siklus II

Pada prinsipnya sama dengan pelaksanaan tindakan siklus I, yang membedakan pada siklus II adalah :

a. Pada siklus II materi ajar yang disajikan mengenai Medan Listrik yang dilaksanakan dalam 2 kali pertemuan (5 jam pelajaran) 
b. Pembelajaran dengan model pembelajaran QODE berbantuan alat peraga dilaksanakan pada pertemuan kedua, dimana guru memfasilitasi peserta didik untuk menyajikan hasil kerja kelompok berupa alat peraga.

3. Pengamatan tindakan (observasi) siklus II

Pada akhir siklus II dilakukan penilaian harian dalam bentuk tes tertulis untuk mendapatkan data hasil belajar IPA. Dari hasil tes tertulis siklus II diperoleh nilai terendah 60, nilai tertinggi 100 dan rerata nilai 80.

4. Refleksi Tindakan Siklus II

Dalam pelaksanaan tindakan ada beberapa hal yang menjadi catatan, yaitu:

a. Pembuatan alat peraga berjalan lancar, siswa telah melakukan uji coba dan telah memahami konsep materi tersebut.

b. Siswa antusias mengikuti pembelajaran dan seluruh anggota kelompok terlibat aktif.

\section{Refleksi Hasil Belajar IPA}

Pada siklus II telah dilaksanakan pembelajaran model QODE dengan menggunakan alat peraga listrik statis pada materi Medan Listrik. Hasil belajar siswa mengalami peningkatan dibandingkan dengan siklus I. Jika dibandingkan dengan siklus I, nilai terendah naik 33,3\% dari 45 menjadi 60. Nilai tertinggi naik 17,6\% dari 85 menjadi 100. Rata-rata nilai naik $14,9 \%$ dari 69,6 menjadi 80 . Persentase jumlah siswa yang telah tuntas belajar juga meningkat.

Tabel 2. Ketuntasan belajar siswa pada siklus II

\begin{tabular}{|c|c|c|c|}
\hline Jumlah Siswa & Belum Tuntas & Tuntas & Persentase \\
\hline 25 & 5 & 20 & $80 \%$ \\
\hline
\end{tabular}

Ketuntasan belajar pada siklus II telah mencapai $100 \%$, berarti telah memenuhi indikator kinerja penelitian yaitu $70 \%$ siswa memperoleh nilai hasil belajar $\geq 80$ pada siklus II sehingga tidak perlu diadakan siklus selanjutnya.

\section{Pembahasan}

Sebagai permasalahan dalam penelitian ini adalah rendahnya hasil belajar IPA. Hal tersebut karena guru belum menggunakan model pembelajaran yang tepat untuk membantu siswa mempelajari materi listrik statis sehingga siswa menganggap bahwa pelajaran IPA sulit, membosankan dan tidak menarik. Perlu pemilihan model yang tepat untuk memecahkan masalah tersebut. Model yang dimaksud adalah Model Pembelajaran QODE berbantu Alat Peraga.

Penelitian tindakan kelas ini terdiri dari 2 siklus, penggunaan model pembelajaran QODE pada siklus I dan II berbeda. Pada siklus I model QODE digunakan secara kelompok tanpa alat peraga sedangkan pada siklus II model pembelajaran QODE digunakan secara kelompok dengan bantuan alat peraga. Hasil pengamatan menunjukkan bahwa penggunaan model pembelajaran QODE berbantu alat peraga berdampak pada hasil belajar IPA.

\section{Hasil Belajar IPA}

Hasil belajar IPA yang diperoleh dari nilai tes tertulis menunjukkan peningkatan dari kondisi awal, siklus I dan siklus II. Peningkatan hasil belajar siswa dapat dilihat pada tabel berikut. 
Vol. 2 No. 1 Februari 2022 e-ISSN : 2797-1031 | p-ISSN : 2797-0744

Tabel 2. Perbandingan hasil belajar siswa

\begin{tabular}{|l|c|c|c|l|}
\hline & Kondisi Awal & Siklus I & Siklus II & $\begin{array}{c}\text { Refleksi dari kondisi awal } \\
\text { ke kondisi akhir }\end{array}$ \\
\hline Nilai minimum & 40 & 45 & 60 & Nilai minimum naik 20 \\
\hline Nilai maksimum & 80 & 85 & 100 & Nilai maksimum naik 20 \\
\hline Rerata nilai & 55,2 & 69,6 & 80 & Rerata nilai naik 24,8 \\
\hline
\end{tabular}

Persentase ketuntasan dari kondisi awal 24\%, pada siklus I naik menjadi $60 \%$ dan pada siklus II ketuntasan naik menjadi $80 \%$. Pada indikator kinerja penelitian, indikator keberhasilan direfleksikan dengan $60 \%$ siswa memperoleh nilai hasil belajar $\geq$ 80 pada siklus I dan $70 \%$ siswa memperoleh nilai hasil belajar $\geq 80$ pada siklus II. Nilai 80 adalah nilai ketuntasan minimal. Dengan melihat ketuntasan belajar maka hasil dari siklus I dan siklus II telah mencapai indikator tersebut. Melalui penggunaan Media Pembelajaran QODE (Questioning, Organizing, Doing and Evaluating) dapat mengoptimalkan hasil belajar IPA materi Listrik Statis pada siswa kelas IX. Sumayyah dari kondisi awal ketuntasan $24 \%$ menjadi kondisi akhir $80 \%$.

\section{Hasil Tindakan}

Berdasarkan perbandingan data kondisi awal, siklus I dan siklus II yang dijabarkan dalam pembahasan dapat disimpulkan tindakan yang dilakukan pada siklus I maupun siklus II membawa peningkatan pada hasil belajar.

Hasil belajar mengalami peningkatan dari rerata 55,2 pada kondisi awal menjadi 80 pada kondisi akhir, berarti meningkat 24,8. Persentase jumlah siswa yang tuntas belajar meningkat dari $24 \%$ menjadi $80 \%$, berarti meningkat 56\%. Dengan demikian hipotesis penelitian yang menyatakan bahwa penggunaan model pembelajaran QODE berbantu alat peraga dapat mengoptimalkan hasil belajar IPA materi listrik statis bagi siswa kelas IX. Sumayyah di SMP Negeri 10 Langsa tahun 2019 dapat terbukti.

\section{KESIMPULAN}

Hipotesis mengatakan melalui penggunaan model pembelajaran QODE berbantu alat peraga dapat megoptimalkan hasil belajar IPA materi listrik statis bagi siswa kelas IX. Sumayyah SMP Negeri 10 Langsa tahun 2019. Dari data empirik diperoleh melalui penggunaan model pembelajaran QODE berbantu alat peraga dapat mengoptimalkan hasil belajar IPA, dari rendah $24 \%$ pada kondisi awal menjadi tinggi $80 \%$, pada kondisi akhir. Artinya penggunaan model pembelajaran QODE berbantu alat peraga dapat mengoptimalkan hasil belajar IPA materi listrik statis bagi siswa kelas IX. Sumayyah SMP Negeri 10 Langsa tahun 2019.

\section{DAFTAR PUSTAKA}

Arikunto, Suharsimi. 2009. Penelitian Tindakan Kelas. Jakarta : Bumi Aksara.

Depdiknas. (2006). Panduan Pengembangan Bahan Ajar IPA. Jakarta: Dirjen Pendidikan Dasar dan menengah. Direktorat PSMP.

Dimiyati dan Mudjiono. (2009). Belajar dan Pembelajaran. Jakarta: PT Rineka Cipta.

Hamalik, O. 2004. Psikologi Belajar dan Mengajar. Bandung: Sinar Baru

Irawati, R. (2015). Gambaran pengenalan model pembelajaran QODE (Questioning, Organizing, Doing and Evaluating) pada guru IPA SMP di kabupaten Probolinggo. Surabaya: Prosiding Seminar Nasional Jurusan Fisika FMIPA-UNESA.

Istarani. 2012. Model Pembelajaran Inovatif. Medan : Media Persada.

Kemdiknas. (2011). Panduan Pengembangan Pem Pembelajaran IPA Secara Terpadu. Jakarta: Direktorat Sekolah Menengah Pertama. 
Muakhidah. 2018. Peningkatan Hasil Belajar IPA Materi Gaya Menggunakan Pendekatan Contextual Teaching Learning (CTL) Dan Alat Peraga Pada Siswa Kelas V MI Al Islam Sutopati 3 Kec. Kajor Kab. Magelang Tahun 2017/2018. Skripsi. FTIK IAIN Salatiga.

Nasution. 1995. Didaktik Asas-Asas Mengajar. Jakarta: Bumi Aksara.

Shoimin, Aris, 2014. Model Pembelajaran Inovatif dalam Kurikulum 2013. Yogyakarta: Arruz Media.

Trianto. (2010). Mendesain Model Pembelajaran Inovatif-Progesif. Jakarta: Bumi Aksara.

Uno \& Nurdin. 2015. Belajar dengan Pendekatan PAIKEM Pembelajaran Aktif, Inovatif, Lingkungan Kreatif, Efektif, Menarik. Jakarta: PT. Bumi Aksara. 